\title{
BIODIVERSITY OF RELICT AND ENDEMIC PLANTS IN SHUTMAN STRICT NATURE RESERVE IN KOSOVO
}

\author{
Haxhi Halilaj ${ }^{1 *}$, Lirika Kupe ${ }^{1}$, Avdyl Bajrami ${ }^{1,}$ Xhavit Mala $^{2}$ \\ ${ }^{1 *}$ Agricultural University of Tirana, Faculty of Agriculture and Environment, Albania; \\ ${ }^{2}$ Ministry of Environment and Spatial Planning -DAPK "Sharr Mountain”, Kosovo; \\ *Corresponding Author Haxhi Halilaj, e-mail: haxhihalilaj@ hotmail.com;
}

Received September 2020; Accepted October 2020; Published November 2020;

DOI: https://doi.org/10.31407/ijees10.425

\begin{abstract}
Shutman Strict Nature Reserve in Kosovo is of great biological and ecological interest because of its distinctive flora and variable environment and landscape. In the present study, 76 endemic and relict species were recorded, belonging to 51 genera and 29 families, and $92.1 \%$ of these species are perennials. Shutman studied flora comprises 55 endemic species, 4 endemic-relict and 17 relicts plants. Out of studied endemic plant species, 48 were Balkan endemics, 7 taxa were subendemics of Balkan and 2 Kosovo endemic species. The most frequent life form was the hemicryptophytes $(69.74 \%)$, followed by the chamaephyte $15.79 \%)$ and geophytes (10.52\%). The flora was mostly composed of Balkan elements with 36 taxa (47.37\%), followed by Boreal elements with 5 taxa (6.58\%) and AlpineCarpathian-Balkan with 4 taxa (5.26\%). Results of this study demonstrated that Shutman Maintain is an important center of the Balkan endemic flora in the area of Kosovo and the Balkan Peninsula. The existence of a diverse and rich endemic flora is of great importance in the conservation of biodiversity in this area.
\end{abstract}

Keywords: Shutman Reserve, vascular plants, endemic and relict plants, life form, refuge. 